\title{
PELATIHANPENGURUSAN JENAZAH SESUAI TUNTUNAN RASULULLAH SAW BAGI MASYARAKAT DI PIMPINAN CABANG MUHAMMADIYAH KECAMATAN SUKARAJA KABUPATEN SELUMA
}

\author{
Dedy Novriadi \\ ${ }^{1)}$ Program Studi Pendidikan Agama Islam, Fakultas Agama Islam, Universitas Muhammadiyah Bengkulu \\ Email : Dedynovriadi@umb.ac.id
}

\begin{abstract}
ABSTRAK
Penyelenggaraan jenazah sangatlah penting karena jika ada seorang muslim yang meninggal disuatu tempat dan tidak ada yang bisa merawatnya dengan benar sesuai dengan tuntunan Rasulullah saw, maka seluruh masyarakat yang tinggal di tempat tersebut akan mendapatkan dosa karena hukum penyelenggaraan jenazah merupakan Fardu Kifayah (kewajiban yang dibebankan kepada umat Islam, tetapi apabila sebagian dari mereka ada yang melaksanakannya, maka terlepaslah kewajiban itu dari yang lainnya).Oleh karena itu harus ada orang muslim yang mampu melakukan pengurusan terhadap jenazah dengan benar sesuai tuntunan Rasulullah saw.Dalam kenyataan masih banyak ditemukan dalam kehidupan seharihari umat Islam yang belum mengetahui bagaimana tata cara pengurusan jenazah. Masih banyak praktek pengurusan jenazah yang berbau bid'ah (larangan yang tidak pernah dilakukan Nabi Muhammad SAW), tidak terkecuali bagi masyarakat yang tinggal di wilayah Pimpinan Cabang Muhammadiyah Kecamatan Sukaraja Kabupaten Seluma. Dewasa ini sedikit orang yang mampu menyelenggarakan pengurusan jenazah sesuai tuntunan Rasulullah SAW.

Metode pelaksanaan yang dilakukan adalah sosialisasi dan pelatihan serta demontrasi. Sosialiasasi dan pelatihan serta demontrasi yaitu memberikan penyuluhan dan pelatihan kepada kepada masyarakat di Pimpinan Cabang Muhammadiyah Kecamatan Sukaraja Kabupaten Seluma.

Berdasarkan dari hasil pelatihan pengurusan jenazah sesuai tuntunan Rasulullah saw bagi masyarakat di Pimpinan Cabang Muhammadiyah Kecamatan Sukaraja Kabupaten Seluma, sebagian besar masyarakat sudah mengetahui tata cara memandikan, mengkafani, mensholatkan dan menguburkan yang sesuai dengan tuntunan Rasulullah SAW.
\end{abstract}

\section{Kata Kunci: Pengurusan Jenazah, Tuntunan Rasulullah SAW}

\section{PENDAHULUAN}

Dalam ajaran Islam, kehormatan manusia sebagai khalifah Allah SWT dan sebagai ciptaan termulia, tidak hanya terjadi dan ada ketika masih hidup di dunia saja. Akan tetapi kemuliaannya sebagai makhluk
Allah SWT tetap ada walaupun fisik sudah meninggal. Kesinambungan kemuliannya sebagai makhluk Allah SWT terjadi karena ruhnya hidup berpindah ke alam lain, yang sering disebut dengan alam barzakh, alam diantara dunia dan akhirat. 
Penghormatan dan pemuliaan tersebut dilakukan sejak mulai dari penyelenggaraan jenazah, yang diteruskan oleh waris atau keluarga yang masih hidup setelah jenazah seseorang meninggal dunia. Karena pentingnya penyelenggaraan jenazah dimulai dengan memandikan jenazah sampai menguburkan jenazah, maka Rasulullah saw memberikan kabar gembira bagi siapa yang mau mengurus jenazah sampai tuntas dengan pahala yang besar, sebagaimana sabda Rasulullah saw:

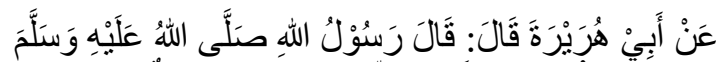

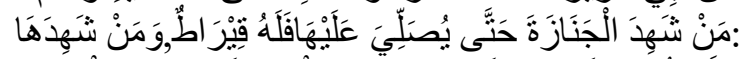

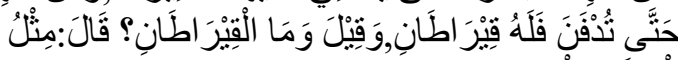

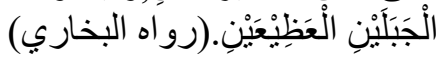

Artinya :

Dari Abu Hurairah r.a bahwa Rasulullah saw bersabda: Barangsiapa mengurus jenazah sampai mensholatkannya, maka baginya satu qirath. Dan barangsiapa mengurus jenazah sampai dimakamkan, maka baginya dua qirath. Seseorang bertanya: Apa dua qirath? Beliau bersabda:

Dua Gunung besarnya. (HR.Bukhary).

Penyelenggaraan jenazah muslim sangatlah penting karena jika ada seorang muslim yang meninggal disuatu tempat dan tidak ada yang bisa merawatnya dengan benar sesuai dengan tuntunan Rasulullah saw, maka seluruh masyarakat yang tinggal di tempat tersebut akan mendapatkan dosa karena penyelenggaraan jenazah merupakan fardu kifayah bagi umat Islam. Oleh karena itu harus ada orang muslim yang mampu melakukan pengurusan terhadap jenazah dengan benar sesuai tuntunan Rasulullah saw, tidak terkecuali bagi masyarakat muslim yang tinggal di wilayah Pimpinan Cabang Muhammadiyah Kecamatan Sukaraja Kabupaten Seluma. Dewasa ini sedikit sekali orang yang mampu menyelenggarakan jenazah dari memandikan sampai selesai menguburkannya semuanya telah dicontohkan dan diajarkan Rasulullah saw tentang itu secara terperinci, lengkap dan sempurna. Walaupun penyelenggaraan jenazah itu merupakan fardu kifayah, tetapi agama mengajurkan supaya sebanyak mungkin orang menyertai sholat jenazah dan mengantarkan jenazah ke makam. Oleh karena itu, kalau seseorang tidak menguasai ilmu tentang aturan agamanya mengenai penyelenggaraan jenazah, akan sangat aib baginya.

Berdasarkan latar belakang di atas, maka penulis tertarik untuk melakukan pengabdian pada masyarakat terkait Pelatihan Pengurusan Jenazah Sesuai Tuntunan Rasulullah SAW Bagi Masyarakat Di Pimpinan Cabang Muhammadiyah Kecamatan Sukaraja Kabupaten Seluma. 


\section{TARGET DAN LUARAN}

Target dari kegiatan pengabdian ini sesuai dengan rencana kegiatan adalah : Masyarakat di Pimpinan Cabang Muhammadiyah Kecamatan Sukaraja Kabupaten Seluma mengetahui tata cara pengurusan terhadap jenazah; memandikan, mengkafani, mensholatkan dan menguburkan yang sesuai dengan tuntunan Rasulullah SAW.

Luaran dalam kegiatan ini adalah :

a. Tersusunnya modul panduan pengurusan jenazah sesuai tuntunan Rasulullah saw bagi masyarakat di Pimpinan Cabang Muhammadiyah Kecamatan Sukaraja Kabupaten Seluma.

b. Masyarakat lebih mandiri dan menguasi cara menghadapi musibah kematian dilingkungan keluarganya dan masyarakat pada umumnya.

\section{METODE PELAKSANAAN}

Kegiatan pengabdian masyarakat ini dilaksanakan di Pimpinan Cabang Muhammadiyah Kecamatan Sukaraja Kabupaten Seluma.

Program pelatihan yang disusun ini merupakan bidang pengabdian pada masyarakat, oleh karena itu metode pelaksanaan yang dilakukan adalah sosialisasi dan pelatihan serta demontrasi.

Sosialiasasi dan pelatihan serta demontrasi yaitu memberikan penyuluhan dan pelatihan kepada masyarakat di Pimpinan Cabang Muhammadiyah Kecamatan Sukaraja Kabupaten Seluma.

Kegiatan pengabdian masyarakat ini dilakukan dengan beberapa metode yaitu, penyuluhan, pelatihan dan demontrasi kepada masyarakat di Pimpinan Cabang Muhammadiyah Kecamatan Sukaraja Kabupaten Seluma.

\section{HASIL DAN PEMBAHASAN}

\subsection{TahapPersiapan}

Dalamtahappersiapaninidilakukan

Observasikemasyarakat di Pimpinan Cabang Muhammadiyah Kecamatan Sukaraja Kabupaten Seluma.Dalam observasi ini di dapatdatatentang kondisimasyarakat dimana sebahagian darimasyarakatini memang belum mengetahui tata cara pengurusan terhadap jenazah; memandikan, mengkafani, mensholatkan dan menguburkan yang sesuai dengan tuntunan Rasulullah SAW.

\subsection{Tahap Pelaksanaan (Sosialisasi)}

Dalamtahapsosialisasiinidilakukan

menjelaskan tata cara pengurusan 
terhadap jenazah; memandikan, mengkafani, mensholatkan dan menguburkan yang sesuai dengan tuntunan Rasulullah SAW di Pimpinan Cabang Muhammadiyah Kecamatan Sukaraja Kabupaten Seluma.

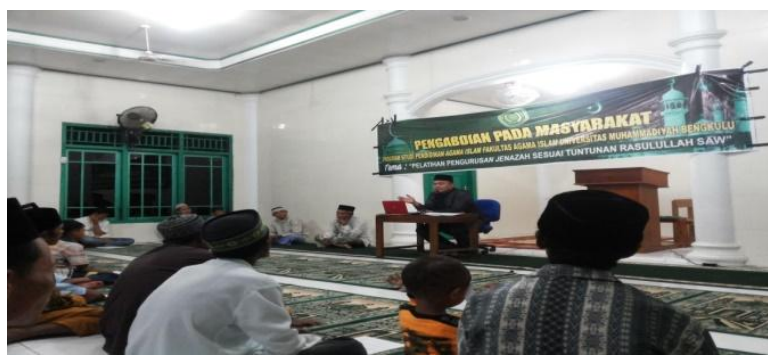

Gambar 1. Sosialiasai Pengurusan Jenazah

\subsection{Tahap Mempraktekan}

\section{(Demontrasi)}

DalamtahapDemontrasiinidilakuka

n Praktek tata cara pengurusan terhadap jenazah; memandikan, mengkafani, mensholatkan dan menguburkan yang sesuai dengan tuntunan Rasulullah SAW di Pimpinan Cabang Muhammadiyah Kecamatan Sukaraja Kabupaten Seluma. Pengurusan jenazah termasuk Syari'at Islam yang perlu diketahui oleh seluruh umat Islam. Hal itu dimaksudkan agar dalam pengurusan jenazah sesuai dengan tuntunan Rasulullah saw. Pengurusan jenazah termasuk salah satu kewajiban umat Islam yang termasuk dalam fardu kifayah, artinya kewajiban yang kalau dikerjakan oleh sebagian umat Islam maka gugurlah kewajiban sebagian umat Islam lainnya. Adapun hal-hal yang harus dilakukan terhadap orang sudah meninggal dunia antara lain

\section{a. Memandikan Jenazah}

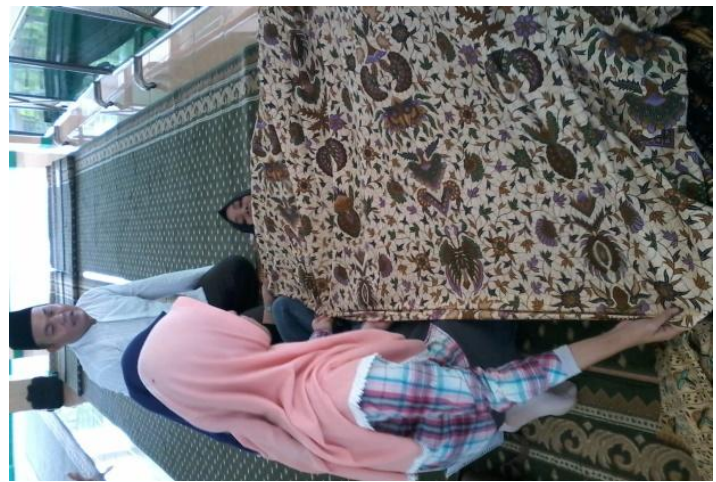

Gambar 3. Praktek Memandikan Jenazah

\section{b. Mengkafani Jenazah}

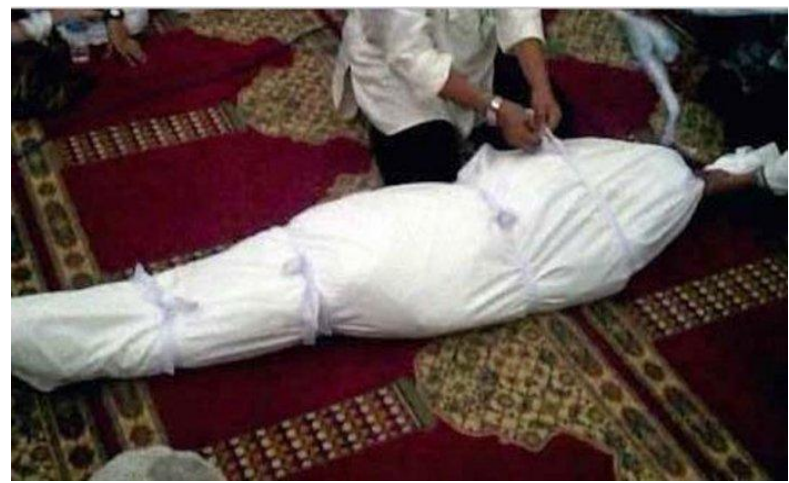

Gambar 4. Praktek Mengkafani 


\section{b. Menshalatkan Jenazah}

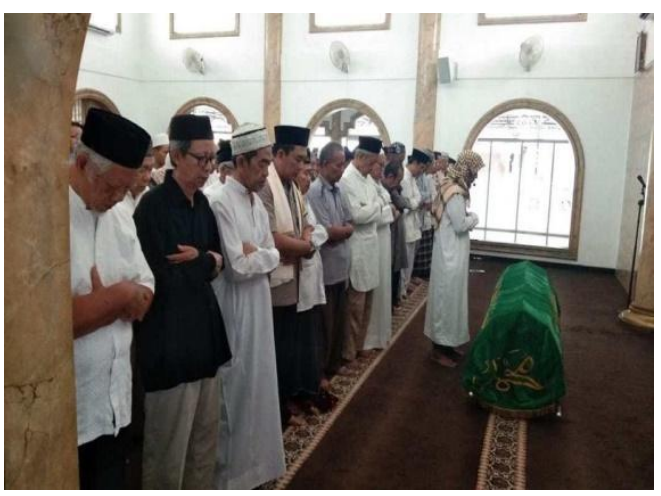

Gambar 5.Praktek Mensholatkan

Jenazah

\section{d. Menguburkan Jenazah}

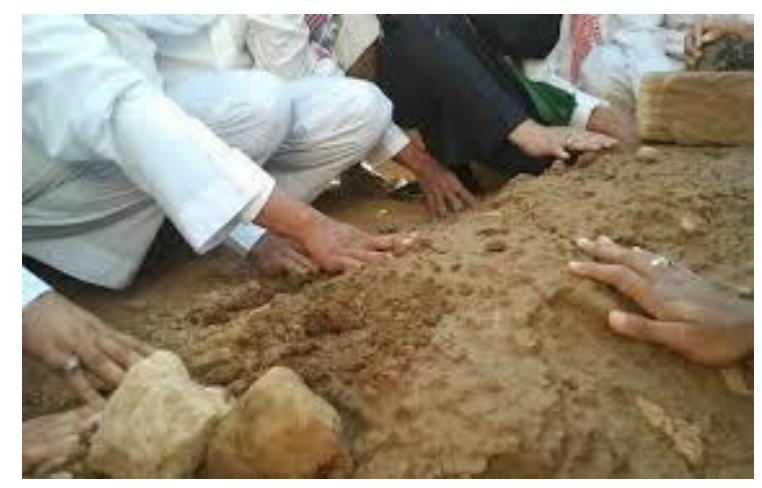

Gambar 6. Praktek Menguburkan

\section{PENUTUP}

\subsection{Kesimpulan}

Berdasarkan dari hasil pelatihan pengurusan jenazah sesuai tuntunan Rasulullah saw bagi masyarakat di Pimpinan Cabang Muhammadiyah Kecamatan Sukaraja Kabupaten Seluma, sebagian besar masyarakat sudah mengetahui bagaimana dalam menyikapi seorang Muslim yang sakaratul maut dan baru meninggal dunia serta pengurusan terhadap jenazah; memandikan, mengkafani, mensholatkan dan menguburkan yang sesuai dengan tuntunan Rasulullah SAW.

\subsection{Saran}

Sesuai dengan hasil kegiatan yang telah dilakukan, maka saran-saran dari kegiatan pengadian pada masyarakat ini adalah:

1. Diharapkan para tokoh agama dan tokoh masyarakat dapat mensosialisasikan kepada masyarakat di Pimpinan Cabang Muhammadiyah Kecamatan Sukaraja Kabupaten Seluma tentang pengurusan terhadap jenazah sesuai tuntunan Rasulullah SAW.

2. Perlunya tindak lanjut mensosialisasikan tentang pengurusan terhadap jenazah sesuai tuntunan Rasulullah SAW kepada pelajar dan remaja sebagai generasi penerus bangsa dan Agama. 


\section{DAFTAR PUSTAKA}

Al Sayid Sabiq. 1980. Fiqhu Al Sunnah. Mesir : Darul Fikri.

Al Hafidz Ibnu Hajar.t.t. Bulugh al Maram. Bandung : Al Ma'arif.

A.Razak, dkk.1984. Terjemahan Hadits Shahih Muslim. Jakarta : Pustaka Al Husna.

Daradjat, Zakiah. 1995. Ilmu Fikih.Yogyakarta: Dana Bhakti Wakaf.

Dedy Novriadi, dkk. 2013.Buku Panduan Ibadah Praktis Bagi Mentor. Bengkulu. BP2I-UMB

Departemen Agama RI.1982.Al Quran dan Terjemahannya. Jakarta: Depag RI.

Hadikusuma, Djarnawi.1983.Kitab Fiqih Berdasarkan Majelis Tarjih. Yogykarta: Persatuan.

Idris, Mahsyar, 2010.Verifikasi dan Catatan Terhadap Kitab Himpunan Putusan Majelis Tarjih Muhammadiyah.Parepare:UMPAR

Press

Jamaluddin, Syakir.2010.Kuliah Fiqih Ibadah.Yogyakarta : LPPI UMY.

Majelis Tarjih Pimpinan Pusat Muhammadiyah.2014

Cet.xxviii.Himpunan Tarjih

Muhammadiyah (HPT). Yogyakarta :

Suara Muhammadiyah.
Pimpinan Wilayah Muhammadiyah DKI Jakarta, 1988. Petunjuk Rasulullah dalam Menghadapi (Mengurusi) Mayat. Jakarta : PWM DKI Jakarta

Pimpinan Pusat Muhammadiyah Majelis Tarjih. 2003. Tanya Jawab Agama 1,2,3,4,5. Yogyakarta : Suara Muhammadiyah.

Pimpinan Pusat Aisyiyah Majelis Tabligh. 2011. Seputar Kematian. Yogyakarta: PP Aisyiyah Majelis Tabligh Shalahudin, Asep.2012.Tuntunan Ibadah Praktis. Yogyakarta: Suara Muhammadiyah. 